\title{
Prevalence of sexually transmitted infections at a tertiary hospital in Tamil Nadu
}

\author{
Durga K. ${ }^{1}$, Karthika K. ${ }^{2 *}$
}

\begin{abstract}
${ }^{1}$ Department of Obstetrics and Gynecology, Sri Lakshmi Narayana Institute of Medical Sciences, Bharath University, Osudu, Puducherry, India

${ }^{2}$ Department of Obstetrics and Gynecology, Thoothukudi Government Medical college and Hospital, The Tamil Nadu Dr. MGR Medical University, Thoothukudi, Tamil Nadu, India
\end{abstract}

Received: 07 June 2017

Accepted: 29 June 2017

\section{*Correspondence:}

Dr. Karthika K.,

E-mail: drkarthicmc2004@gmail.com

Copyright: (C) the author(s), publisher and licensee Medip Academy. This is an open-access article distributed under the terms of the Creative Commons Attribution Non-Commercial License, which permits unrestricted non-commercial use, distribution, and reproduction in any medium, provided the original work is properly cited.

\begin{abstract}
Background: Sexually transmitted infections (STIs) present a huge burden of disease and adversely affect the reproductive health of people. The disease prevalence is about $6 \%$ in India. This study is done to determine the prevalence of STIs in women of reproductive age (15-49yrs) attending gynaec outpatient block at Institute of Obstetrics and Gynaecology, Chennai and to identify the risk factors.

Methods: It is a prospective analytical study conducted at IOG from Febraury 2010 to January 2011 where 1000 women of reproductive age attending gynec op were included of which 500 women were asymptomatic and 500 women were symptomatic for STIs. A well-structured proforma was prepared for selection of women, history, examination, investigations and treatment. Asymptomatic women were also screened and treated. Partners were also screened and treated. Depending upon the statistical data, the risk factors were identified and analysed.

Results: Overall prevalence of STI was $27.2 \%$ of which $22.5 \%$ was in symptomatic group and $4.7 \%$ in asymptomatic group. Bacterial vaginosis was the commonest STI. The important risk factors identified were age group between 2630 years, high risk sexual behaviours, poor socioeconomic factors, poor menstrual hygiene and lack of contraception. Conclusions: STIs cause major health problem and it is important to diagnose and treat them at the earliest. The importance of STIs has been more widely recognised since the advent of the HIV/AIDS epidemic, and there is good evidence that their control can reduce HIV transmission. Women diagnosed with one STI should be screened for other STI due to coexistant infections. Screening and treatment of partners and follow-up tests of cure should be performed wherever possible.
\end{abstract}

Keywords: Bacterial vaginosis, Sexually transmitted infections

\section{INTRODUCTION}

Sexually transmitted infections (STIs) are a major global cause of acute illness, infertility and long-term disability associated with severe medical and psychological consequences. WHO estimated that 340 million new cases of syphilis, gonorrhoea, chlamydia and trichomoniasis have occurred throughout the world in 1999 in men and women aged 15-49 years. The largest number of infection occur in the region of South East Asia followed by African countries ${ }^{1}$.There are more than 20 pathogens that are transmissible through sexual intercourse. Many of them are curable by appropriate antimicrobial treatment.

The WHO states - "In developing countries, STIs and their complications are the top five diseases for which adult (15-49yrs) seek health care. In women of child 
bearing age STIs (excluding HIV) are second only to maternal factors as cause of disease, death and healthy life cost."

The exact magnitude of STIs are frequently unknown due to the asymptomatic nature of infections. Moreover, only part of the symptomatic population seeks health care and it is just only tip of the iceberg. The social stigma that is usually associated with STIs may result in people seeking care from alternative providers or not seeking care at all. As a result, report-based STI surveillance systems tend to underestimate substantially the total number of new cases.

In general, the prevalence of STIs tends to be higher in urban residents, in unmarried individuals and in young adults. STIs tend to occur at a younger age in females than in males. The highest rates of STIs are generally found between the ages of 15 and 35 which are the most sexually active years.

STIs enhance the sexual transmission of HIV infection. The presence of an untreated STI (ulcerative or nonulcerative) can increase the risk of both acquisition and transmission of HIV by 10 times. Effective management of STIs reduce HIV infection in general population by $40 \% .^{2}$

The emergence of HIV and identification of STIs as a cofactor have further lent a sense of urgency for formulating a programmatic response to address this important public health problem. ${ }^{3}$ Hence, it is necessary to identify STI population by relatively easy and cheap diagnostic methods and treat them early, thereby reducing the disease transmission, minimising the duration of illness and preventing the development of complications.

Until the 1990s, STIs were commonly known as Venereal diseases/ Sexually transmitted disease (STD). Veneris is the Latin genitive form of the name Venus, the Roman goddess of love.

\section{The common causative organisms}

- Bacterial: Chancroid (Haemophilus ducreyi), Chlamydia (Chlamydiatrachomatis), Granuloma inguinale (Klebsiella granulomatis), Gonorrhea (Neisseria gonorrhoeae) Syphilis (Treponema pallidum)

- Fungal: Candidiasis (candida albicans)

- Viral: Viral hepatitis (Hepatitis B, C virus), Herpes simplex (Herpes simplex virus 1,2), HIV (Human Immunodeficiency Virus), HPV (Human Papillomavirus). Molluscum contagiosum (molluscum contagiosum virus)

- Parasites: Crab louse (Pthirus pubis), Scabies (Sarcoptes scabiei)

- $\quad$ Protozoal: Trichomoniasis (Trichomonas vaginalis)

\section{Global estimates}

WHO estimates that 340 million new cases of STIs have occurred worldwide in 1999. The largest number of new infections occurred in the region of South and Southeast Asia, followed by Sub-Saharan Africa, Latin America and the Caribbean. However, the highest rate of new cases per 1000 population has occurred in sub Saharan Africa. About $60 \%$ of these infections occur in young people $<25$ years of age. ${ }^{1}$

Commonly reported STIs among sexually active adolescent girls both with and without lower genital tract symptoms include chlamydia (10-25\%), gonorrhea (3$18 \%)$, syphilis $(0-3 \%)$, Trichomonas vaginalis $(8-16 \%)$ and herpes simplex virus $(2-12 \%)$.

AIDS is the single largest cause of mortality in SubSaharan Africa. The prevalence of multiple STIs was $7.5 \%$ in a study conducted by Grover, Rajagopal et al. ${ }^{4-6}$

Table 1: Odds of transmission per unprotected sexual act with an infected person.

\begin{tabular}{|c|c|c|}
\hline & Known risks & $\begin{array}{l}\text { Possible or } \\
\text { unknown risks }\end{array}$ \\
\hline & \multicolumn{2}{|l|}{$\begin{array}{l}\text { Chlamydia (30- } \\
50 \%)\end{array}$} \\
\hline & \multicolumn{2}{|l|}{ Scabies } \\
\hline & \multicolumn{2}{|l|}{ Crabs } \\
\hline \multirow[t]{7}{*}{$\begin{array}{l}\text { Vaginal sex- } \\
\text { women }\end{array}$} & $\begin{array}{l}\text { Gonorrhea (50 to } \\
90 \% \text { ) }\end{array}$ & Hepatitis C \\
\hline & $\begin{array}{l}\text { Hepatitis B (50- } \\
70 \%)\end{array}$ & \\
\hline & Herpes & \\
\hline & HIV (0.1\%) & \\
\hline & HPV (5\%) & \\
\hline & Syphilis & \\
\hline & Trichomoniasis & \\
\hline
\end{tabular}

A large percentage of STIs are asymptomatic which leaves a greater risk of passing the disease on to others. Depending on the disease, some untreated STIs can lead to infertility, chronic pain or even death. Early identification and treatment results in less chance of transmission of disease and may improve the outcomes of treatment.

There is often a window period after initial infection during which an STI test will be negative. During this period, the infection may be transmissible. The duration of this period varies depending on the infection and the test.

Diagnosis may also be delayed by reluctance of the infected person to seek a medical professional. One report indicated that afflicted people turn to the Internet rather than to a medical professional for information on STIs to a higher degree than for other sexual problems. ${ }^{7}$ 


\section{The common STI Syndromes are}

- Cervicitis

- Vaginal discharge

- Genital ulcer

- Genital ulcer (allergic to pencillin)

- Genital ulcer vesicles

- Lower abdominal pain

- Bubo (inguinal swelling)

\section{METHODS}

It is a prospective analytical study conducted at IOG from Febraury 2010 to January 2011 where 1000 women of reproductive age attending gynec op were included of which 500 women were asymptomatic and 500 women were symptomatic for STIs. The study group was selected according to inclusion and exclusion criteria.

Table 2: Investigations of STIs.

\begin{tabular}{|c|c|c|}
\hline Specimen & Test & Organisms \\
\hline \multicolumn{3}{|c|}{ Vaginal discharge } \\
\hline \multirow[t]{2}{*}{ Smear } & Wet mount & $\begin{array}{l}\text { Trichomonas and } \\
\text { Bacterial vaginosis }\end{array}$ \\
\hline & $\mathrm{KOH}$ mount & $\begin{array}{l}\text { Candida } \\
\text { Bacterial vaginosis } \\
\text { (Whiff Test) }\end{array}$ \\
\hline \multicolumn{3}{|l|}{ Swab } \\
\hline & Gram stain & Candida \\
\hline & Culture & $\begin{array}{l}\text { Candida } \\
\text { Trichomonas }\end{array}$ \\
\hline \multicolumn{3}{|c|}{ Vaginal discharge } \\
\hline & $\mathrm{pH}<4.5$ & $\begin{array}{l}\text { Normal vaginal } \\
\text { secretions } \\
\text { Candidiasis }\end{array}$ \\
\hline & $>4.5$ & Bacterial vaginosis \\
\hline \multicolumn{3}{|c|}{ Endocervix } \\
\hline Smear & $\begin{array}{l}\text { Gramstain } \\
\text { ELISA }\end{array}$ & $\begin{array}{l}\text { Gonococci } \\
\text { Chalymdia }\end{array}$ \\
\hline Swab & culture & Gonococci \\
\hline \multicolumn{3}{|c|}{ Urethral discharge } \\
\hline Smear & Gram stain & Gonococci \\
\hline Swab & Culture & Gonococci \\
\hline \multicolumn{3}{|l|}{ Rectal } \\
\hline Swab & Culture & Gonococci \\
\hline Ulcer & Wright stain & HSV II \\
\hline Smear & $\begin{array}{l}\text { Wet mount } \\
\text { KOH mount } \\
\text { Gram stain }\end{array}$ & $\begin{array}{l}\text { Trichomonas / } \\
\text { Bacterial vaginosis } \\
\text { Candida } \\
\text { Gonococci }\end{array}$ \\
\hline Swab & Culture & Gonococci \\
\hline \multirow[t]{4}{*}{ Serum } & ELISA & HIV \\
\hline & RPR & Syphilis \\
\hline & $\begin{array}{l}\text { ELISA for } \\
\text { HBsAg }\end{array}$ & Hepatits B \\
\hline & $\begin{array}{l}\text { EIA for Anti } \\
\text { HCV }\end{array}$ & Hepatitis C \\
\hline
\end{tabular}

\section{Inclusion criteria}

- women of reproductive age (15 to $49 \mathrm{yrs}$ ) attending IOG

- agreeing to participate in the study

- willing for follow up

- willing for partner notification

\section{Exclusion criteria}

- $<15$ and $>49 y r s$

- bleeding per vagina

- pregnant women

- unmarried women with no sexual contacts

The sampled women were explained about the aim of the study. Informed written consent was obtained. Patients were divided in two groups (control and study). History, examination, investigation and treatment done as per the protocol. Partners of STI positive patients were also screened and treated. The investigations done were listed below.

\section{Data analysis}

All collected data were entered in MS excel sheet. Analysis would be done using the Multivariate logistic regression using SPSS version 15 (Tools used Chi-square analysis).

\section{RESULTS}

The prevalence of STI was found to be $27.2 \%$. The prevalence of STI in asymptomatic group was $4.7 \%$ and in symptomatic group was $22.5 \%$.

In asymptomatic group, the prevalence of candida was highest $5.8 \%$. In symptomatic group, the prevalence of bacterial vaginosis was highest $24.2 \%$. Overall the prevalence of bacterial vaginosis was the highest $13.4 \%$. $(\mathrm{p}<0.001)$.

The prevalence of STI was high in the age group of 26-30 years and low in the age group $>35$ years.9.1\% of STIs were diagnosed in the age group of $15-20$ years. P $<0.01$

About $43.3 \%$ of STI positive women were housemaid (independent risk-50.8\%) and $20.5 \%$ were building labourers (independent risk-58.9\%). This table shows that building labourers were at high risk of acquiring STI. P $<0.01$.

STI were more commonly seen in women who were illiterate $(29.7 \%)$ and who had studied up to primary level of education $(56.25 \%)$. The prevalence of STI was low in women who had higher education. (greater than secondary level $<0.7 \%$ ) P $<0.01$. 
Table 3: Prevalence of STI.

\begin{tabular}{|lllllll|}
\hline Infections & $\begin{array}{l}\text { Asymptomatic } \\
\text { positive (500) }\end{array}$ & $\begin{array}{l}\text { Asymptomatic } \\
\text { negative (500) }\end{array}$ & $\begin{array}{l}\text { Symptomatic } \\
\text { positive (500) }\end{array}$ & $\begin{array}{l}\text { Symptomatic } \\
\text { negative (500) }\end{array}$ & $\begin{array}{l}\text { Total } \\
(\mathbf{1 0 0 0})\end{array}$ & Prevalence \\
\hline $\begin{array}{l}\text { Bacterial } \\
\text { Vaginosis }\end{array}$ & $13(2.6 \%)$ & - & $121(24.2 \%)$ & - & 134 & $13.4 \%$ \\
\hline Trichomonas & $2(0.4 \%)$ & - & $10(2.0 \%)$ & - & 12 & $1.2 \%$ \\
\hline Candida & $29(5.8 \%)$ & - & $51(10.2 \%)$ & - & 80 & $8.0 \%$ \\
\hline Gonococcus & - & - & $2(0.4 \%)$ & - & 2 & $0.2 \%$ \\
\hline Chlamydia (197) & $1(0.2 \%)$ & - & $10(2.0 \%)$ & - & 11 & $1.1 \%$ \\
\hline HSV & - & - & $3(0.6 \%)$ & - & 3 & $0.3 \%$ \\
\hline HIV & $2(0.4 \%)$ & - & $5(1.0 \%)$ & - & 7 & $0.7 \%$ \\
\hline Syphilis & - & - & - & - & - & - \\
\hline HBV (192) & - & - & - & - & - & - \\
\hline HCV (192) & - & - & - & - & - & - \\
\hline $\begin{array}{l}\text { Concomittant } \\
\text { infections }\end{array}$ & - & - & $23(4.6 \%)$ & - & 23 & $2.3 \%$ \\
\hline Total & 47 & 453 & 225 & 275 & 272 & \\
\hline Prevalence & $4.7 \%$ & $45.3 \%$ & $22.5 \%$ & $27.5 \%$ & $27.2 \%$ & \\
\hline
\end{tabular}

Table 4: Age distribution.

\begin{tabular}{|lllll|}
\hline Age group (years) & Total STI positives & Total STI negatives & Total population & \% in positives \\
\hline $15-20$ & 25 & 26 & 51 & 9.1 \\
\hline $21-25$ & 54 & 94 & 248 & 19.8 \\
\hline $26-30$ & 184 & 199 & 383 & 67.6 \\
\hline $31-35$ & 6 & 172 & 178 & 2.2 \\
\hline $36-40$ & 2 & 88 & 90 & 0.7 \\
\hline $41-45$ & 1 & 48 & 49 & 0.3 \\
\hline $46-49$ & 0 & 1 & 1 & 0 \\
\hline
\end{tabular}

Table 5: Occupation of self.

\begin{tabular}{|llllll|}
\hline Occupation of self & $\begin{array}{l}\text { Asymptomatic } \\
\text { positive }\end{array}$ & $\begin{array}{l}\text { Symptomatic } \\
\text { positive }\end{array}$ & $\begin{array}{l}\text { Total } \\
\text { positives }\end{array}$ & $\%$ & $\begin{array}{l}\text { \% risk of each } \\
\text { occupation }\end{array}$ \\
\hline Housewife & 10 & 33 & 43 & 15.8 & 10.8 \\
\hline Agricultural labourers & 14 & 31 & 45 & 16.5 & 21.9 \\
\hline Housemaid & 17 & 101 & 118 & 43.3 & 50.8 \\
\hline Building labourers & 5 & 51 & 56 & 20.5 & 58.9 \\
\hline Commercial social workers & - & - & - & 0 & - \\
\hline Others & 1 & 9 & 10 & 3.6 & 13. \\
\hline
\end{tabular}

Figure 2 shows that women with STI had poor obstetric outcomes like abortion, IUD and neonatal death. Bacterial vaginosis was the most common STI associated with them.

About $74.6 \%$ of STI positive women and $77.3 \%$ of STI negative women did not use any form of contraceptive methods. Copper $\mathrm{T}$ and male condoms were used to certain extent in STI positive women. Overall the contraceptive methods were frequently used in the STI negative population.

Women whose partners were symptomatic for STI had higher risk of acquiring STI. 31 out of 37 women $(83.7 \%)$ who had symptomatic partners were diagnosed to have STI of which $64.9 \%$ were symptomatic women.

This shows the percentage distribution of the symptoms. Vaginal discharge was the most common symptom in symptomatic positive (95.6\%) and symptomatic negative $(88.7 \%)$ women followed by Itching (33.8\%), Dyspareunia (24\%), Urinary complaints (20\%) and Lower abdomen pain (18.2\%). In the asymptomatic positive group, cervical erosion (34\%) followed by cervical congestion $(25.5 \%)$ were the predominant signs. In the symptomatic positive group, apart from discharge $(94.7 \%)$ cervical congestion $(67.6 \%)$ followed by cervical erosion $(46.7 \%)$ were the predominant signs $-\mathrm{P}<0.001$. 
Table 6: Distribution of signs in each study group.

\begin{tabular}{|c|c|c|c|c|c|c|}
\hline \multirow{2}{*}{$\begin{array}{l}\text { Signs } \\
\text { Congestion }\end{array}$} & \multicolumn{2}{|c|}{$\begin{array}{l}\text { Asymptomatic } \\
\text { positive }\end{array}$} & \multirow{2}{*}{$\begin{array}{c}\text { Asymptomatic negative } \\
\qquad 22\end{array}$} & \multicolumn{2}{|c|}{$\begin{array}{l}\text { Symptomatic } \\
\text { positive }\end{array}$} & \multirow{2}{*}{$\begin{array}{l}\text { Symptomatic negative } \\
\qquad 77\end{array}$} \\
\hline & 12 & $25.5 \%$ & & 152 & $67.6 \%$ & \\
\hline Erosion & 16 & $34.0 \%$ & 3 & 105 & $46.7 \%$ & 73 \\
\hline Hypertrophy & 7 & $14.9 \%$ & 1 & 44 & $19.6 \%$ & 29 \\
\hline Discharge & 4 & $8.5 \%$ & 2 & 213 & $94.7 \%$ & 244 \\
\hline Intertrigo & 1 & $2.1 \%$ & 0 & 8 & $3.6 \%$ & 0 \\
\hline $\begin{array}{l}\text { Cervical motion } \\
\text { tenderness }\end{array}$ & 0 & 0 & 0 & 11 & $4.9 \%$ & 3 \\
\hline Fornix tenderness & 0 & 0 & 0 & 23 & $10.2 \%$ & 5 \\
\hline Excoriations & 0 & 0 & 0 & 4 & $1.8 \%$ & 0 \\
\hline Vesicles & 0 & 0 & 0 & 3 & $1.3 \%$ & 0 \\
\hline Ulcer & 0 & 0 & 0 & 9 & $4.0 \%$ & 0 \\
\hline Erythema & 0 & 0 & 0 & 11 & $4.9 \%$ & 0 \\
\hline
\end{tabular}

Table 7: Investigation results.

\begin{tabular}{|c|c|c|c|c|}
\hline Infection & Investigations & $\begin{array}{l}\text { Asymptomatic } \\
\text { positive }\end{array}$ & $\begin{array}{l}\text { Symptomatic } \\
\text { positive }\end{array}$ & Total cases \\
\hline \multirow{3}{*}{ Bacterial vaginosis } & Vaginal discharge wet mount & 13 & 121 & 134 \\
\hline & Vaginal discharge $\mathrm{Ph}$ & 13 & 121 & \\
\hline & Vaginal discharge Whiff test & 13 & 121 & \\
\hline \multirow[t]{3}{*}{ Trichomonas } & Vaginal discharge wet mount & 2 & 10 & 12 \\
\hline & Vaginal discharge culture & 2 & 10 & \\
\hline & Ulcer wet mount & 0 & 1 & \\
\hline \multirow[t]{4}{*}{ Candidiasis } & Vaginal discharge $\mathrm{KOH}$ mount & 28 & 51 & 80 \\
\hline & Vaginal discharge Gram stain & 28 & 51 & \\
\hline & Vaginal discharge culture & 29 & 51 & \\
\hline & Ulcer-KOH & 0 & 2 & \\
\hline \multirow[t]{8}{*}{ Gonococcus } & Vaginal discharge Gram stain & 0 & 2 & 2 \\
\hline & Endocervix Gram stain & 0 & 2 & \\
\hline & Endocervix Culture & 0 & 2 & \\
\hline & Urethral smear Gram stain & 0 & 1 & \\
\hline & Urethral smear Culture & 0 & 1 & \\
\hline & Rectal Culture & 0 & 0 & \\
\hline & Ulcer gram stain & 0 & 0 & \\
\hline & Ulcer culture & 0 & 0 & 0 \\
\hline Chlamydia & Endocervix ELISA & 1 & 10 & 11 \\
\hline HSV & Ulcer and vesicles Leishmann stain & 0 & 3 & 3 \\
\hline HIV & Serum ELISA & 2 & 5 & 7 \\
\hline Syphilis & Serum RPR & 0 & 0 & 0 \\
\hline
\end{tabular}

In asymptomatic group, the nature of discharge was predominantly serous / mucoid. In symptomatic group, though serous discharge was common, mucopurulent discharge and curdy white discharge were characteristically seen.

Vaginal discharge syndrome (81.8\%) was the most common STI syndrome followed by lower abdomen pain syndrome $(17.6 \%)$ and genital ulcer syndrome $(0.6 \%)$. It follows the same order in both symptomatic positive and negative groups. This shows the percentage distribution of the causative organisms in STI syndromes. Most common infections associated with vaginal discharge syndrome were bacterial vaginosis (27.4\%) and candidiasis $(12.0 \%)$. Most common infections associated with lower abdomen pain syndrome were bacterial vaginosis $(10.2 \%)$ and Chlamydia $(8.5 \%)$. Genital ulcer syndrome was most commonly caused by herpes.

Bacterial vaginosis was the most common STI identified though candidiasis was common in asymptomatic women. HSV, Chlamydia and Gonoccocal infection were more specific for symptomatic women. 


\section{DISCUSSION}

The prevalence of STI was $27.2 \%$ in this study. The prevalence of STI in asymptomatic group was $4.7 \%$ and in symptomatic group $22.5 \%$. In asymptomatic group, the prevalence of candida was highest $5.8 \%$. In symptomatic group, the prevalence of bacterial vaginosis was highest $24.2 \%$. On the whole, the prevalence of bacterial vaginosis was the highest $13.4 \%$ followed by candida (8\%) and trichomonas (1.2\%) No cases of syphilis, hepatitis $\mathrm{B}$, hepatitis $\mathrm{C}$ were reported.

The prevalence of concomitant infections (mixed infections) were $2.3 \%$ of which candida and trichomonas contribute to $0.8 \%$; candida and bacterial vaginosis $0.7 \%$; candida, trichomonas and bacterial vaginosis $0.5 \%$. Similar prevalence was reported by Thomas et al in his study where the prevalence of STIs was $14.6 \%$ in Tamil Nadu. ${ }^{8}$ Community prevalence of HIV and hepatitis B infection was $1.8 \%$ and $5.3 \%$ respectively. The prevalence of HIV was $0.7 \%$ in this study. Sami et al in his hospital based study at Quetta also reported that bacterial vaginosis $(30.7 \%)$ was the most common STI, followed by candidiasis $(10 \%)$, trichomoniasis $(7.2 \%)$ and gonorrhea $(1.35 \%){ }^{9}$

\section{Analysis of the risk factors}

Age

The prevalence of STI was high in the age group 26-30 years about $50 \%$ and low in the age group $>35$ years, $4 \%$. The prevalence of STI increases steadily upto 30 years thereafter it declines. $49 \%$ of women in the age group of 15-20 years had STI which was because of the natural hormonal mileu of vagina. Kosambiya et al in his study at Surat also reported high prevalence of STI in the age group of $26-30$ years. ${ }^{10}$ However, study by Thomas et al in-Tamil Nadu reported that age group between 30-39 years $(35.8 \%)$ and $20-29$ years $(35.3 \%)$ were at high risk of contracting STI. ${ }^{8}$ Mishra et al also reported $70 \%$ of the women were in the age group of 25-44 yrs similar to that reported by Bhatnagar et al. ${ }^{11,12}$ These findings suggest that interventions for prevention of STI should begin at an early age group.

\section{Monthly income}

$49.2 \%$ of women whose monthly income was $<2000 \mathrm{had}$ high risk of acquiring STI which indicates that low socioeconomic group a risk factor similar to Kosambiya et al in his study. ${ }^{10}$

\section{Occupation of self and spouse}

About $43.3 \%$ of STI positive women were housemaid (independent risk-50.8\%) and 20.5\% were building labourers (independent risk of $58.9 \%$ - indicates the highrisk nature of the occupation). Men working out of station $(45.7 \%)$ and lorry drivers $(35.9 \%)$ were at high risk of acquiring and transmitting STIs. Thomas et al in his study found that $42.5 \%$ were unemployed, majority of them were housewifes. ${ }^{8}$ Jas Kosambiya et al stated that $71 \%$ of women were housewifes. ${ }^{10}$ Jasmin Helen Prasad et al in his study of RTI in women at Vellore district reported that $55 \%$ of STI positive women were performing household chores and $32 \%$ worked as agricultural labourers. ${ }^{12}$ Sami et al in his study stated that spouses who were jobless / labourers were risk factors for STI.

\section{Education in self and spouse}

In this study STI were more commonly seen in women who were illiterate $(29.7 \%)$ and who had primary education $(56.25 \%)$. The prevalence of STI was low in women who had good education (more than secondary level $<0.7 \%$ ). The prevalence of STI was high in women whose partner were either illiterate or studied upto primary level of education $(77.16 \%)$. Thomas et al in his study stated that $25.3 \%$ were illiterate, $32.4 \%$ had primary education, $30.3 \%$ had high school education and $13.8 \%$ had high education. ${ }^{8}$

\section{Years of marriage and status of self}

Women who were married for $<5$ years $(75 \%)$ were at increased risk of acquiring STI than women who were married $>10$ years $(14.5 \%)$. Those women who were married for the second time or to whom they were second wife had $55.5 \%$ increased risk of acquiring and transmitting STI than those who were married once. In this study $95 \%$ of women were married and $5 \%$ were divorced/ widow. Thomas et al in his study reported that $80 \%$ were married, $17 \%$ were unmarried and $2.3 \%$ either divorced or widow. ${ }^{8}$

\section{Poor obstetric outcomes}

Women with poor obstetric outcomes like abortion, IUD, neonatal death were at high risk of acquiring STI. Most of them had symptomatic STI. Bacterial vaginosis was the most common organism associated with poor obstetric outcomes. $20 \%$ of abortions were associated with bacterial vaginosis.

\section{Menstrual hygiene}

About $86 \%$ of women who were diagnosed as having STI reused the same clothes whereas only $13.5 \%$ of women use fresh clothes or sterile napkins. Reusing the same clothes was a risk factor to acquire STI.

\section{Sexual behaviours in self and spouse}

$85.13 \%$ of women practising high risk sexual behaviours were diagnosed to have STI infection, of which $74.03 \%$ were symptomatic. $60.4 \%$ of STI positive women had partners with high risk sexual behaviours in which most 
of the women were symptomatic. Thus, high risk sexual behaviours were risk factors for STI.

\section{Contraception}

About $74.6 \%$ of STI positive women did not use any form of contraceptive methods. Intrauterine devices were used by $6 \%$ of women, male condoms by $6 \%$ and oral contraceptives by $5 \%$ in STI positive women. $8 \%$ of STI positive women have undergone tubectomy. Bacterial vaginosis was the most common organism associated with all forms of contraceptive methods except in OCPs $(36 \%)$ where candida is common. Jasmin Helen Prasad et al reported in his study that Intrauterine devices were used by only $4 \%$ of women, oral contraceptives by $2 \%$, condoms and abstinence by $1 \%$ each and $17 \%$ had a tubal ligation. $^{13}$

\section{Partner symptoms}

$83.7 \%$ of STI positive women had partners symptomatic for STI. Most common STI diagnosed in these women were candida (32.4\%) and bacterial vaginosis (24.3\%)

\section{Past history of STI in self and spouse}

$54.5 \%$ reported to have past history of STI in symptomatic group and $9 \%$ in asymptomatic STI. Among the affected women $47.7 \%$ of spouse had past history of STI. Bacterial vaginosis $(21.2 \%)$ and candida (15.2\%) were the commonest STI. 50\% of women who had gonoccocal infection reported to have past history of STI in self. Kosambiya et al stated that $45 \%$ reported to have past history of STI in the past. ${ }^{10}$

\section{Past treatment history of STI in self and spouse}

About $57.5 \%$ of women had taken some form of treatment (allopathy, ayurveda, sidha) wheras $42.5 \%$ of women had improper treatment (home remedies, temple priest). $92.8 \%$ of men had taken some form of treatment (allopathy, ayurveda, sidha) wheras $7.2 \%$ of men had improper treatment. Thomas et al reported in his study that $51.9 \%$ took allopathic treatment, $22.6 \%$ ayurveda, $15.8 \%$ siddha and $0.8 \%$ had visited temple priest. ${ }^{2}$

\section{Symptoms}

Vaginal discharge was the most common symptom $(95.6 \%)$ followed by Itching $(33.8 \%)$, Dyspareunia (24\%), Urinary complaints $(20 \%)$ and Lower abdomen pain (18.2\%). Symptoms like fever and genital ulcer were specific for symptom positive group. Mishra et al study that stated vaginal discharge (98\%) was the most common complaint followed by lower abdomen pain $(61.3 \%)$ and ulcers $(16.6 \%) .{ }^{11}$ Kosambiya et al and Sami et al also reported that vaginal discharge $(84 \%)$ was the most common presenting symptom followed by lower abdomen. ${ }^{9,10}$

\section{Signs}

In the asymptomatic STI positive group cervix erosion (34\%) followed by cervix congestion $(25.5 \%)$ were the predominant signs. In the symptomatic positive group, apart from discharge $(94.7 \%)$, cervix congestion (67.6\%) followed by cervix erosion $(46.7 \%)$ were the predominant signs. Signs like cervical motion tenderness, forniceal tenderness, intertrigo, excoriation, vesicles, ulcer, erythema were found in the symptomatic group positive for STI. Intertrigo, excoriation and erythema were associated with candida infection. Cervical motion tenderness and Forniceal tenderness were associated with chlamydial and bacterial vaginosis infection. Genital ulcers were seen not only in herpes infection but also in candida and mixed infections.

\section{Nature of discharge}

Discharge in asymptomatic group were either serous $(50 \%)$ or mucoid $(50 \%)$. None were mucopurulent or curdy white. Discharge in symptomatic group were serous $(49.5 \%)$ or mucoid $(40.65 \%)$. Mucopurulent and curdy white were seen in the symptomatic group. Serous and mucous discharge were seen in bacterial vaginosis, candida and trichomonas infection. Mucopurulent discharge was mostly seen in Gonococci and Chlamydial infection however small percentage are associated with bacterial vaginosis, candida and trichomonas infection. Curdy white discharge was specific for candidial infection. Mishra et al reported in his study about the nature of vaginal discharge. ${ }^{11}$ It was curdy white in $21 \%$ of cases and mucopurulent in $38 \%$ of cases.

\section{STI syndrome and the causative organisms}

Vaginal discharge syndrome $(81.8 \%)$ was the most common STI syndrome followed by lower abdomen pain syndrome (17.6\%) and genital ulcer syndrome $(0.6 \%)$. Most common infections associated with vaginal discharge syndrome were bacterial vaginosis $(27.4 \%)$ and candidiasis $(12.0 \%)$.

Most common infections associated with lower abdomen pain syndrome were bacterial vaginosis (10.2\%) Chlamydia (8.5\%). Genital ulcer syndrome was most commonly caused by herpes. Thomas et al in his study reported that genital discharge was the most common STI syndrome $(38.4 \%)$ followed by genital ulcer syndrome $(2.7 \%)$ and lower abdomen pain syndrome $(0.6 \%){ }^{8}$

\section{Co-morbidities}

Diabetic women were at increased risk of acquiring candidiasis $(21.7 \%)$.

\section{CONCLUSION}

The prevalence of STIs among women of reproductive age (15-49 yrs) was $27.2 \%$ of which $4.4 \%$ were 
asymptomatic stressing the need for effective screening methods. The important risk factors identified were high risk sexual behaviours, poor socio-economic status, poor menstrual hygiene and lack of contraceptive usuage. The importance of STIs has been more widely recognised since the advent of the HIV/AIDS epidemic, and there is good evidence that their control can reduce HIV transmission. Women diagnosed with one STI should be screened for other STI due to coexistant infections. Screening and treatment of partners and follow-up tests of cure should be performed wherever possible. Barrier contraceptive use, STI awareness programmes and hazards of blood transfusion should be promoted.

\section{ACKNOWLEDGMENTS}

Authors would like to thank Prof. Dr. T. Radhabai Prabu, former Director, Institute of Obstetrics and Gynaecology, Egmore, Chennai for her valuable support and guidance. Author wish to acknowledge patients who readily consented in the study and the blessings of the Almighty without which this work would not have been possible. Author also wish to acknowledge family members for their moral support.

Funding: No funding sources

Conflict of interest: None declared

Ethical approval: The study was approved by the Institutional Ethics Committee

\section{REFERENCES}

1. World Health Organization. Global prevalence and incidence of selected curable sexually transmitted infections: overview and estimates. Geneva: WHO; 2001.

2. Gilson L, Mkanje R, Grosskurth H, Mosha F, Picar J, Gavyole A, et al. Cost-effectiveness of improved treatment services for sexually transmitted diseases in preventing HIV-1 infection in Mwanza Region, Tanzania. Lancet. 1997;350:1805-9.

3. National guidelines on prevention, management and control of RTI/ STI; 2007.

4. Grover S, Rajagopal R. Trends of sexually transmitted infections: A 33 year experience. Med J Armed Forces India. 2009;65(3):235-6.
5. Varghese B, Maher JE, Peterman TA, Branson BM, Steketee RW. Reducing the risk of sexual HIV transmission: quantifying the per-act risk for HIV on the basis of choice of partner, sex act, and condom use. Sex Transm Dis. 2002;29(1):38-43.

6. Burchell A. Modeling the sexual transmissibility of human papillomavirus infection using stochastic computer simulation and empirical data from a cohort study of young women in Montreal, Canada. Am J Epidemol. 2006;169(3):534-43.

7. The Cringe Report. By Susan Quilliam.; J Fam Plann Reprod Health Care. 2011;37(2):110-2.

8. Thomas K, Thyagarajan SP, Jeyaseelan L, Varghese JC, Krishnamurthy P, Bai LA et al. Community prevalence of sexually transmitted diseases and human immunodeficiency virus infection in Tamil Nadu, India: a probability proportional to size cluster survey. Natl Med J India. 2002;15(3):135-40.

9. Shehla Sami, Shahnaz Naseer Baloc, Vaginitis and Sexually Transmitted Infections in a Hospital Based Study. JPMA. 2005;55:242.

10. Kosambiya, Desai. RTI/ STI prevalence among urban and RURAL WOMEN OF SURaT: a community based study. Indian J Sex Transm Dis. 2009;30:89-93.

11. Mishra A, Verma P, Marathe N. Study of the Profile of Patients with STDs Attending an STD Clinic in J.A.H., Gwalior Indian J Community Med. 2008; 33(4):263-4.

12. Bansal KM, Singh K, Bhatnagar S. Prevalence of lower RTI among married females in the reproductive age group (15-45). Health Population. 2001;24:157-63.

13. Helen J, Sulochana P, Kathleen A, Kurz M. reproductive tract infections among young married women in Tamil Nadu, India. Int Fam Plann Perspec. 2005;31(2):73-82.

Cite this article as: Durga K, Karthika K.

Prevalence of sexually transmitted infections at a tertiary hospital in Tamil Nadu. Int J Reprod Contracept Obstet Gynecol 2017;6:3573-80. 